NBER WORKING PAPER SERIES

\author{
'OPTIMAL' POLLUTION ABATEMENT - \\ WHOSE BENEFITS MATTER, AND HOW MUCH?
}

\author{
Wayne B. Gray \\ Ronald J. Shadbegian \\ Working Paper 9125 \\ http://www.nber.org/papers/w9125 \\ NATIONAL BUREAU OF ECONOMIC RESEARCH \\ 1050 Massachusetts Avenue \\ Cambridge, MA 02138 \\ September 2002
}

Financial support for the research from the National Science Foundation (grant \# SBR-9410059) and the Environmental Protection Agency (grant\#R-828824-01-0) is gratefully acknowledged. We are also grateful to the many people in the paper industry who have been willing to share their knowledge with us. Thomas McMullen, Charles Griffith, George Van Houtven, and Tim Bondelid helped us work with the EPA datasets; thanks to Mahesh Podar and John Powers in the EPA Office of Water, sponsors of the NWPCAM model. We received helpful comments on earlier drafts of the paper from Eli Berman, Matt Kahn, Arik Levinson, Gilbert Metcalf, and seminar participants at the EPA's National Center for Environmental Economics, the Public Choice Meetings, the Second World Congress of Environmental and Resource Economists, and the NBER Empirical Environmental Policy Research Conference. Capable research assistance was provided by Aleksandra Simic, Martha Grotpeter, and Bhramar Dey. Any remaining errors or omissions are the authors'. The views expressed herein are those of the authors and not necessarily those of EPA, NSF or the National Bureau of Economic Research.

(C) 2002 by Wayne B. Gray and Ronald J. Shadbegian. All rights reserved. Short sections of text, not to exceed two paragraphs, may be quoted without explicit permission provided that full credit, including (C) notice, is given to the source. 
'Optimal' Pollution Abatement - Whose Benefits Matter, and How Much?

Wayne B. Gray and Ronald J. Shadbegian

NBER Working Paper No. 9125

September 2002

JEL No. Q28, L51

\begin{abstract}
We examine measures of environmental regulatory activity (inspections and enforcement actions) and levels of air and water pollution at approximately 300 U.S. pulp and paper mills, using data for 1985-1997. We find that levels of air and water pollution emissions are affected both by the benefits from pollution abatement and by the characteristics of the people exposed to the pollution. The results suggest substantial differences in the weights assigned to different types of people: the benefits received by out-of-state people seem to count only half as much as benefits received in-state, although their weight increases if the bordering state's Congressional delegation is strongly pro-environment. Some variables are also associated with greater regulatory activity being directed towards the plant, but those results are less consistent with our hypotheses than the pollution emissions results. One set of results was consistently contrary to expectations: plants with more nonwhites nearby emit less pollution. Some of our results might be due to endogenous sorting of people based on pollution levels, but an attempt to examine this using the local population turnover rate found evidence of sorting for only one of four pollutants.
\end{abstract}

Wayne B. Gray

Economics Department

Clark University

950 Main Street

Worcester, MA 01610

and NBER

wgray@clarku.edu
Ronald J. Shadbegian

Economics Department

University of Massachusetts, Dartmouth

285 Old Westport Road

Pittsburgh, PA 15260

and U.S. EPA, NCEE

rshadbegian@umassd.edu 


\section{‘Optimal' Pollution Abatement - Whose Benefits Matter, and How Much?}

\section{INTRODUCTION}

In this paper we examine the optimal allocation of environmental regulation across pulp and paper mills. The optimal allocation depends on the costs and benefits of pollution abatement at the plant, as seen by the regulator. The direct costs of pollution abatement at a particular plant are related to the plant's age, size, and technology, while the benefits are related to the extent of the pollution being generated and the number of people affected. Past studies comparing benefits and costs have focused on fairly simple measures of abatement benefits. In this study we develop more sophisticated measures of air and water benefits from pollution abatement based on the SLIM-3 Air Dispersion Model and the Environmental Protection Agency's (EPA) National Water Pollution Control Assessment Model (NWPCAM) respectively. We expect that regulators should impose stricter regulation on plants located in areas with greater benefits from pollution abatement. However, we also consider political factors that may influence the allocation of pollution abatement. The focus of our paper is on spatial differences across plants in the distribution of benefits from pollution abatement and in the characteristics of the population living nearby. Responding to some of these population measures may be socially optimal if certain population groups are more sensitive to pollution, but in many cases these measures suggest self-interested behavior by regulators seeking to maximize the political support for their actions.

We perform our analyses using a plant-level panel data set on approximately 300 pulp and paper mills from 1985-1997. We find substantial supporting evidence for both benefits and 
population characteristics affecting environmental outcomes. Plants with larger benefits to the overall population emit less air and water pollution, and those with more kids and elders nearby emit less air pollution. Plants located in poor neighborhoods get less regulatory attention and emit more pollution. Plants located near state boundaries emit more pollution, with these effects reduced if the nearby states have more pro-environment Congressmen. Not every result fits those predicted by theory: the percentage nonwhite near the plant, expected to reduce regulatory attention (assuming nonwhites have less political clout), is actually associated with lower emissions. The results for our measures of regulatory activity tend to be less often significant, and sometimes carry unexpected signs.

One important caveat on our results is the cross-sectional nature of our demographic data. Some of the results could be explained as reverse causation or sorting: poor people move towards dirty neighborhoods because housing is cheaper there; families with sensitive individuals such as kids and elders avoid dirty neighborhoods. It is difficult for us to control for such endogeneity because most paper mills are very old, so we cannot include pre-siting demographics in the analysis. Our attempt to test for sorting (using the degree of population turnover near the plant) finds significant evidence in favor of sorting for only one of the four pollutants (particulates), while the two water pollutants find significant evidence against sorting.

Some of the differences in results for different regulatory measures pose further research questions. There is a pattern of unexpected signs for regulatory actions, where factors associated with fewer regulatory actions are often associated with less, not more, pollution. We would have expected opposite signs on these coefficients, and do find opposite signs in some cases. Is this an artifact of the data, or does it represent a real difference in the process by which regulatory 
activity is allocated in different situations? Similarly, we find different effects on air and water pollution of being near the Canadian border: do these reflect real differences across pollution media in the mechanisms for ensuring international cooperation on pollution control?

The remainder of the paper is organized as follows. Section 2 provides a brief survey of the relevant literature. In section 3 we provide some background on the pulp and paper industry. Section 4 outlines our model of the regulator's allocation of pollution abatement across plants. In section 5 we present our empirical methodology and a description of our data. Section 6 contains our results and finally we present some concluding remarks and possible extensions in section 7 .

\section{PREVIOUS STUDIES}

A few studies have addressed the issues raised above, providing empirical estimates of the impact of political boundaries, demographics, and political activism on exposure to pollution. For example, Helland and Whitford (2001), using annual county-level data from the Toxic Release Inventory (1987-1996), find that facilities located in counties on state borders (border counties) have systematically higher air and water pollution releases than facilities located in non-border counties: facilities in border counties emit 18 percent more air pollution and 10 percent more water pollution than facilities in non-border counties. Kahn (1999) also finds some evidence of a transboundary externality problem with particulates. Kreisel et al (1996) find that minorities are not disproportionately exposed to TRI emissions, but find some evidence that the poor are disproportionately exposed to TRI emissions. Arora and Cason (1999) find evidence of racial injustice only in the south. In particular, Arora and Cason find that race is a significantly positive determinant of TRI releases in non-urban areas of the south. 
Hamilton $(1993,1995)$ examines whether exposure to environmental risk varies by demographics and political activism. Using data at the 'zip-code neighborhood level,' he relates the capacity expansion/contraction decisions of commercial hazardous waste facilities to race, income, education, and level of political activity (voter turnout), finding that capacity expansions are negatively correlated with voter turnout. Jenkins, Maguire, and Morgan (2002) show that minority communities receive lower 'host' fees for the siting of land fills while richer communities receive higher 'host' fees. Wolverton (2002) examines the issue of the location decision of 'polluting' plants. Previous studies indicate that 'polluting' plants tend to locate in poor and minority neighborhoods. However, Wolverton shows that once you consider the characteristics of the community at the time the plant is sited that contrary to popular opinion race no longer matters and that poor neighborhoods actually attract disproportionately less 'polluting' plants.'

\section{PULP AND PAPER INDUSTRY BACKGROUND}

During the past 30 years environmental regulation has increased considerably both in terms of stringency and levels of enforcement. In the late 1960 s environmental rules were primarily enacted at the state level, and were not vigorously enforced. Since the creation of the Environmental Protection Agency (EPA) in the early 1970's the federal government has been the lead player in proposing and developing stricter regulations, and in encouraging greater emphasis on enforcement (much of which is still performed by state agencies, following federal guidelines). The expansion in environmental regulation has imposed large costs on traditional

\footnotetext{
${ }^{1}$ Been (1994) and Been and Gupta (1997) find mixed results for environmental injustice in the citing of hazardous waste facilities when considering the characteristics of the neighborhood at the time of citing - however, their results are based on data sets with only 4 and 10 observations respectively.
} 
'smokestack' industries, like the pulp and paper industry, which is one of the most impacted industries due to its sizable generation of both air and water pollution.

The pulp and paper industry as a whole faces a high degree of environmental regulation. However, plants within the industry can face very different impacts from regulation, depending in part on the technology being used (pulp and integrated mills vs. non-integrated mills ${ }^{2}$ ), the plant's age, the plant's location, and the level of regulatory effort directed at the plant. The most important determinant of the regulatory impact is whether or not the plant contains a pulping process. Pulp mills begin with raw wood (chips or entire trees) and use a variety of techniques to separate out the wood fibers, which are then used to produce paper. The most common form of pulping in the U.S. is the Kraft technique, which separates the wood into fibers using chemicals. A large number of plants also use mechanical pulping (giant grinders separating out the fibers), while still others use some combination of heat, other chemicals, and mechanical methods. Once the fibers are separated out, they can be bleached and combined with water to produce a slurry. After the pulping stage is complete, residual matter remains which historically was released directly into rivers (hence water pollution), but now must first be treated. The pulping process is energy intensive, so most pulp mills have their own power plant, and thus are significant sources of air pollution. The pulping processes may also involve hazardous chemicals, such as the use of chlorine bleaching in Kraft pulp mills, which can create trace amounts of dioxin, raising the concern over toxic releases.

The paper-making process is not nearly as pollution intensive as pulping. Non-integrated mills either purchase pulp from other mills or use recycled wastepaper. During the papermaking process, the slurry (more than $90 \%$ water at the beginning) is laid on a rapidly-moving

\footnotetext{
${ }^{2}$ Integrated mills produce their own pulp and non-integrated mills purchase pulp or use recycled wastepaper.
} 
wire mesh which progresses through a succession of dryers in order to remove the water, thereby creating a continuous sheet of paper. The energy required during this stage is less than during the pulping stage, but it can still cause air pollution concerns if the mill produces its own power. Finally, during the drying process some residual water pollution is created. However, both of these pollution concerns are much smaller than those created during the pulping process.

The past 30 years has seen large reductions in pollution from the paper industry, with the advent of secondary wastewater treatment, electrostatic precipitators, and scrubbers. In addition to these end-of-pipe control technologies, some mills have altered their production process, more closely monitoring material flows to lower emissions. Overall these alterations have been much more prevalent at newer plants, which were at least partly designed with pollution controls in mind - some old pulp mills were deliberately built on top of the river, so that any spills or leaks could flow through holes in the floor for 'easy disposal.' These rigidities can be partially or completely offset by the tendency for most regulations to include grandfather clauses exempting existing plants from the most stringent requirements - e.g. until recent standards limiting NOx emissions, most small existing boilers were exempt from air pollution regulations.

\section{MODEL OF POLLUTION ABATEMENT REGULATION}

Why do profit-maximizing plants employ resources to abate pollution emissions? If pollution were a pure externality, with all the burden falling on those who live downwind or downstream, we would not expect to see any profit-maximizing plant spend money on pollution abatement. Some market-based mechanisms like consumer demand for 'green' products or managerial taste for 'good citizenship' may provide incentives for plants to abate pollution. However, we believe that the main motivation for controlling pollution emissions in the U.S. is 
government regulation of pollution, especially for the air and water pollutants being considered in this paper, so we model the amount of pollution abatement as being determined by regulators rather than by the polluting firms. One could instead employ other models, in which pressure from regulators is supplemented by pressure from customers and community groups, or in which the polluting firms are concerned about some groups of people but not others, affecting where pollution levels are greater. These alternative models could lead to analyses similar to those presented here (explaining why pollution levels from paper mills differ depending on which groups of people are affected by the pollution). We are also assuming that differences in regulatory pressures among U.S. paper mills are primarily determined at the state level, so we view the state as the relevant jurisdiction for political concerns.

A socially optimal government regulator maximizes social welfare by increasing the stringency of environmental regulation (requiring greater pollution abatement) up to the point where the marginal benefit from another unit of abatement is equal to the marginal cost of that abatement. In equation (1), the regulator would choose different optimal abatement values $\mathrm{Ai}^{*}$ for each plant, based on differences in factors affecting their marginal benefits and marginal costs of abatement. The marginal costs of abatement differ across plants based on their production technology, size, and age. The marginal benefits of abatement also differ across plants, driven especially by the number (and characteristics) of the people near the plant who are being exposed to the pollution. Assuming that the marginal cost of pollution abatement increases with stringency (or at least cuts the marginal benefit curve from below), an increase in the marginal benefits curve (or decrease in the marginal costs curve) results in an increase in the desired level of pollution abatement and more stringent environmental regulation. Therefore $\mathrm{dAi} * \mathrm{dPLANTi}<0$ for PLANT characteristics that raise marginal costs, and $\mathrm{dAi} * \mathrm{dPEOPLEi}>0$ 
for PEOPLE characteristics that raise marginal benefits.

\section{(1) $\mathrm{MC}\left(\mathrm{PLANT}_{\mathrm{i}}, \mathrm{A}_{\mathrm{i}}{ }^{*}\right)=\mathrm{MB}\left(\mathrm{PEOPLE}, \mathrm{A}_{\mathrm{i}}{ }^{*}\right)$}

Our analysis focuses on the differences across plants in the marginal benefits of pollution abatement $(\mathrm{MBi})$, though we do include plant characteristics affecting abatement costs as control variables. We model the regulator as adding up the marginal benefits from pollution reductions for all people living around a plant, as shown in equation (2) below. The locations of the people are indexed by $\mathrm{x}$ and $\mathrm{y}$. The marginal benefits $\mathrm{MBi}$ for pollution reductions at a given plant will depend heavily on the number of people in the area (measured by $\rho_{x y}$, the population density at a given point) and the emissions that they are exposed to $\left(E_{x y}\right)$. People may also differ in their susceptibility to pollution exposure $\left(S_{x y}\right)$, which should affect MBi. The 'base' $S_{x y}$ value would be 1 , with deviations from this affecting MBi. Finally, the regulator may choose $\alpha_{x y}$ to value certain people less than others when calculating benefits (in which case $\alpha_{x y}$ would be less than 1).

\section{(2) $M B i=\iint_{x y} \alpha_{x y} S_{x y} E_{x y} \rho_{x y} d x d y$}

Why would $\alpha_{\mathrm{xy}}$ differ across people affected by pollution? One strand of the literature raises concerns with "Environmental Justice", suggesting that groups with less political influence (e.g. the poor or minorities) are discriminated against by regulatory agencies (i.e. are assigned a smaller value of $\alpha_{x y}$ ) which aim at maximizing political clout. Politically active people who strongly favor environmental issues might put more pressure on regulators, and hence get a larger value of $\alpha_{x y}$. For plants located near a state (or country) boundary, the benefits 
from pollution reduction may accrue to people in other jurisdictions for whom $\alpha_{x y}$ might be expected to be zero (or at least less than one). However, some countervailing pressures may arise to offset the latter transboundary effect on regulatory activity.

The creation of a federal EPA in 1972 was at least in part designed to limit cross-state pollution flows, and EPA oversight of state regulatory decisions may be stricter for plants near state boundaries. In addition to a dummy for a plant being located near the border with another state, we include a measure of the pro-environment stance of the neighboring state's Congressional delegation, since presumably the airing of the neighboring state's objections to any transboundary pollution is likely to occur in a national setting.

In the case of Canada two agreements exist which are designed to limit the levels of transboundary pollution: 1) Canada-United States Great Lakes Water Quality Agreement (GLWQA) of 1972 and 2) Canada-United States Air Quality Agreement (AQA) of 1991. ${ }^{3}$ The GLWQA establishes that the U.S. and Canada will act to restore and preserve the chemical, physical and biological soundness of the Great Lakes Basin Ecosystem and it contains a number of goals and guidelines to reach those goals. The AQA is the first bilateral pact between the U.S. and Canada aimed at controlling transboundary air pollution caused by sulfur dioxide and nitrogen oxide emissions. ${ }^{4}$ Given these two agreements it is possible that plants along the Canadian border will face more stringent (or at least no less stringent) environmental regulation.

\footnotetext{
${ }^{3}$ A memorandum of intent has been in place since 1981.

${ }^{4}$ For more information on both of these agreements see the web site (http://www.ijc.org/ijcweb-e.html) of the International Joint Commission which was created by the International Boundary Waters Treaty Act of 1909.
} 


\section{DATA AND EMPIRICAL METHODOLOGY}

Our study measures the relationship between regulatory activity and emissions, and characteristics of the surrounding population, using data on the intensity of environmental regulation faced by U.S. pulp and paper mills. We use data on both air and water pollution, to measure the enforcement and monitoring activity directed towards each mill, along with the relative stringency of the pollution limits faced by the mill. To measure actual outcomes from regulation at the mill we use data on both air and water pollution emissions at the mill. Our analysis controls for a variety of plant- and firm-specific characteristics, as well as the past compliance status of the mill. We also include a number of other control variables designed to capture characteristics of the location of the mill that could influence the level of regulatory activity.

We use models of the spread of pollution to estimate the relative impacts of the pollution on people living near the plant. On the air pollution side, the model utilizes an air dispersion model, SLIM-3, which calculates the total impacts of pollution on the surrounding population separately at each plant. The air dispersion model incorporates information from the pollution source (stack height and characteristics of the pollutants being emitted) and meteorological data (mixing height, wind directions and speeds) to calculate the aggregate exposure at all points within a wide circle around the plant. The exposure data is combined with measures of the number of people living near the plant and estimates from the literature on the health impact of pollutant exposures to quantify the overall dollar benefits from reducing air pollution at each plant [see Shadbegian et al. (2000) for more details].

On the water pollution side we use data from the EPA's National Water Pollution Control Assessment Model (NWPCAM). This model includes discharge data for over 50,000 industrial 
and 13,000 municipal water polluters, combined with stream and river flow data to calculate the transport of pollutants downstream and the resulting water quality on a mile-by-mile basis for every affected stream. Of the paper mills in our dataset, 231 have data present in the NWPCAM model. For each of these mills, we first calculate a baseline model using current discharges and store the water quality results. We then estimate 5 scenario models, increasing the pollution discharged from the mill by a wide range of amounts, and measuring how each scenario affects water quality downstream of the plant. Our monetary measures of the benefits of pollution abatement are based on an experimental version of the NWPCAM model being developed for EPA at Research Triangle Institute, which uses a continuous water quality index (0-100) rather than the traditional four-valued outcomes (unusuable, boatable, fishable, swimmable), allowing for a more precise valuation of water quality changes. Changes in water quality in each stream mile are evaluated in dollar terms using a formula based on the work of Carson and Mitchell (1993). These dollar values are then combined with state population and river miles to estimate the total dollar benefits of pollution reduction (in terms of improved usability) for each scenario. These costs are divided by the amount of additional pollution being discharged in that scenario, providing us with a per-unit benefit of pollution reduction. The largest per-unit value from the 5 scenarios is used to estimate the marginal benefits of pollution abatement at that mill.

Detailed data on the characteristics of the population within a 50-mile radius of each plant, including age distribution, racial composition, and within-jurisdiction residency, are based on the 1990 U.S. Census of Population, as compiled in the Census-CD datasets prepared by Geolytics, Inc. This provides information based on detailed geographic areas (block groups). Distances are calculated between the paper mill and the centroid of each block group to determine which block groups fall within 50 miles of the mill, and the block group values for 
each population characteristic are aggregated to get the overall value for each mill.

In past studies we developed a comprehensive database of U.S. pulp and paper mills to study the impact of environmental regulation on plant-level productivity and investment. This database includes published plant-level data from the Lockwood Directory and other industry sources to identify each plant's production, investment, productivity, age, production technology, and corporate ownership. We add financial data taken from Compustat, identifying firm profitability.

Our pulp and paper mill data is merged with annual plant-level information on regulatory enforcement, compliance, and quantities of pollution, for both air and water pollution, taken from EPA regulatory databases. Regulatory enforcement and compliance data for 1985-1997 come from the EPA's Envirofacts and Integrated Data for Enforcement Analysis databases, as do the water pollution discharges data for Biochemical Oxygen Demand (BOD) and Total Suspended Solids (TSS). These datasets allow us to differentiate between two different types of regulatory actions - enforcement actions (e.g. notice of violation) and inspections. Based on conversations with regulators, the number of enforcement actions is more likely to be connected with problems at the plant, while the number of inspections is more connected with the plant's size. Air pollution emissions data for particulates (PM10) and sulfur dioxide (SO2) comes from the Aerometric Information Retrieval System database for 1985-1990 and from the National Emissions Inventory for 1990-1997.

Our analyses consider two different measures of the environmental regulatory pressures faced by each plant. The number of inspections and the number of enforcement actions received by the plant provide direct measures of regulatory attention. The level of air pollution emissions and water pollution discharges from the plant provide an indirect measure of the regulatory 
pressures faced by the plant, all else equal (assuming that other variables included in the analyses control for differences in the amount of pollution from the plant in the absence of regulation).

Each dependent variable Yit is a function of PLANT and PEOPLE characteristics, as well as STATE variables and year dummies:

(3) $Y_{i t}=f\left(P_{L A N T}\right.$ it, PEOPLE $i t$, STATE $i t$, YEAR $)$

where $\mathrm{Y}$ is one of the eight dependent variables in our analysis: Air and Water Pollution Inspections and Enforcement, Water Discharges of BOD and TSS, and Air Emissions of PM10 and SO2. Since increased regulatory activity will be seen (directly) in more inspections and enforcement actions, and (indirectly) in less air and water pollution, we expect to find opposite signs for the coefficients in the regulatory activity and pollution quantity equations.

First, let us review the plant-, firm-, state-, and county-level control variables included in each model. These controls include lagged compliance status, plant capacity, plant age, firm financial condition, county attainment status (air only), major source and public health effects (water only), and state environmental attitudes. All the results presented here include state dummies, but the models without state dummies tend to lead to similar conclusions (results available from authors upon request). To avoid having the state dummies absorb too much of the cross-plant variation, we only include state dummies for states with 5 or more plants in the given regression (e.g. the air pollution inspection model includes 22 state dummies, with the base group being all other non-specified states).

In terms of plant-level controls we include a lagged measure of regulatory compliance (COMPLAG). Previous research has shown a strong relationship between compliance and enforcement [Magat and Viscusi (1990); Deily and Gray (1991); Nadeau (1997); and Gray and 
Shadbegian (2000)]. We also include pulp and paper capacity (PULP/PAPER CAPACITY) to control for plant size, a dummy variable to indicate if the plant was established after 1960 (NEW PLANT), and a dummy variable to indicate if the plant is the only paper or pulp mill owned by the firm (SINGLE). We also include the number of the plant's Occupational Safety and Health Agency's violations (OSHA VIOL), since previous research has shown that OSHA violations are positively correlated with EPA violations [see Gray and Shadbegian (2000)]. To indicate the financial health of the plant we include a measure from Compustat of the owning-firm's rate of return on its assets (RETURN ON ASSETS).

We include three additional variables to control for exogenous factors affecting the level of regulatory stringency faced by the plant. On the air side we include a dummy variable to indicate if the plant is located in a county that is in non-attainment status with respect to particulate standards (NONTSP; in our data non-attainment for sulfur dioxide is much less common, and nearly always overlaps with particulate non-attainment, so we focus on particulates for all equations). On the water side we include a numeric rating from EPA's Majors Rating Database indicating the extent to which the plant is a large water polluter (MAJORS) and a dummy variable to indicate if the plant discharges into a stream whose water quality has potential health effects, due to being a source of drinking water (PUBLIC HEALTH).

We control for the state-level regulatory climate using GREEN VOTE, a measure of support for environmental legislation by that state's Congressional delegation. The League of Conservation Voters calculates a scorecard for each member of Congress on environmental issues, with data available back to the early 1970s. We use the average score for the state's House of Representative members in our analysis. We also measured the overall inspection activity in each state for each year by the total number of inspections in the state divided by the 
number of plants in the EPA database for that state (STATE AIR INSPECTIONS and STATE WATER INSPECTIONS). The unemployment rate in the state for that year (UNEMP) and percent of the county designated as urbanized (URBAN) round out our control variables.

Now consider the variables which are at the heart of our analyses, those influencing the marginal benefits from pollution abatement at a particular mill (MBi in equation 2). As described above, we have information on the expected benefits per unit of pollution reduction (AIRBEN and WATBEN). On the air pollution side, we also have the percentage of the nearby population under the age of 6 (KIDS) and those 65 and over (ELDERS) representing groups with greater sensitivity to air pollution $\left(\mathrm{S}_{\mathrm{xy}}\right.$ in equation 1$)$. We would expect each of them to be positively related to regulatory activity (inspections and enforcement actions), and negatively associated with pollution quantities.

Differences in $\alpha_{x y}$ across people are measured with several variables. We test for Environmental Justice factors by including two measures of potentially "less valued" populations: poor and minorities. POOR is the percentage of the nearby population living below the poverty line. The minority variable is the percentage of the population that is nonwhite (NONWHITE). We would expect both to be negatively associated with regulatory activity and positively associated with pollution levels.

A positive influence on $\alpha_{x y}$ is expected to come from voter activity, measured using voter turnout in the previous presidential election (TURNOUT), which should be positively associated with regulatory activity. This sort of voter activity to overcome externalities is discussed in Olson (1965). However, it is possible that in some cases a majority of the electorate could oppose environmental regulation, so that higher turnout need not always increase regulation. Thus we include an interaction between turnout and state membership in conservation 
organizations (TURNOUT*CONVMEMB), which would be expected to have a positive association with regulatory activity.

We test for the effects of political boundaries by including two simple dummy variables indicating whether the plant is within 50 miles of another jurisdiction (STATE BORDER or CANADIAN BORDER). For these plants, some of their pollution may "spill over" to the other jurisdiction. All else equal, regulators should care less about such pollution, so regulatory activity should be diminished for those plants. However, the other jurisdiction(s) could respond strongly to any transboundary pollution. Depending on the institutional arrangements in place, the political costs associated with transboundary pollution could be larger than the costs of intrastate pollution. For cross-state pollution, the sensitivity of the other state to transboundary pollution (and hence the pressure to reduce such pollution) is presumed to be associated with that state's GREEN VOTE measure of pro-environmental Congressional support.

An alternative approach to these benefit-related variables is to disaggregate the total benefits received by the surrounding population into those received by different groups, in an effort to see whether the coefficient on benefits differs across groups. To our regressions we add an interaction between the total benefits and the share of the surrounding population in each group, so that the coefficients on the interaction terms show the differences across groups. To measure transboundary effects on the air pollution side we assume that the benefits are distributed proportionately to the fraction of the population within 50 miles of the plant that is out-of-state. On the water pollution side we measure the benefits for each out-of-state river segment directly (where a river forms the border between states, half of the benefit is allocated to each state).

We estimate the eight different equations for the dependent variables measuring 
regulatory stringency using two statistical techniques. For both air and water pollution we measure stringency as the number of inspections (INSP) and enforcement actions (ENFORCE) a plant receives in a given year. Since both INSP and ENFORCE are often zero and are otherwise relatively small integers, we estimate the equations using a Poisson model (actually, we use a Negative Binomial model, to allow for the observed over-dispersion of the data, relative to the simpler Poisson model). For the four pollution quantity equations, we use ordinary least squares on the logarithm of emissions quantities because of the wide dispersion in emissions across plants.

\section{RESULTS}

Table 1 contains the means and standard deviations (along with variable descriptions) of all variables used in this study. Note that the number of observations varies across the models being estimated, depending on the availability of data for the dependent variable and some specific explanatory variables. We have more data for regulatory activity (inspections and enforcement actions) than we do for pollution quantities. To avoid having too many different sample sizes, we restrict the pollution quantity estimation to plants which have both pollutants reported. To simplify Table 1 , all of the control variables have their values reported only for the largest dataset, corresponding to air pollution regulatory activity.

In our data the average plant-year observation receives nearly ten times as many inspections as enforcement actions: approximately two air or water pollution inspections per year and one air or water enforcement action every three or more years. The distribution of enforcement actions is skewed in our data, with many plants receiving none and others receiving several. There is also substantial variation across plants in their air emissions and water 
discharges.

Considering the control variables, the marginal benefits from pollution abatement vary substantially for both air and water pollution. There is much less variation in the age-related demographics variables (KIDS and ELDERS) compared to the 'environmental justice' variables (POOR and NONWHITE). Most plants are within 50 miles of a state border, while a sizable fraction are near the Canadian border. Most plants are in compliance with air and water regulations ( $84 \%$ and $70 \%$ compliance rates respectively). Most plants were in existence by $1960(75 \%)$ and are owned by a firm with more than one paper mill (75\%). Approximately half of the plants $(43 \%)$ have water pollution discharges that have potential public health impacts and $34 \%$ of the plants are located in counties that are not in attainment with particulate emission standards.

Tables 2 and 3 present the results of the basic model for air pollution and water pollution regulation respectively. Consider first the control variables in each equation. We see that lagged compliance is associated with significant reductions in both pollution quantities and regulatory activity for air pollution, but for water pollution the only marginally significant impact comes in reduced water inspections. OSHA violations are surprisingly associated with lower pollution quantities (though significant only for SO2), and more enforcement actions. The effects of plant capacity seem to come primarily in terms of pulping capacity, rather than paper capacity (larger coefficients and more frequently significant). Larger plants generate more pollution and face more regulatory activity (except water inspections). Plants in urban areas generate less pollution, but also (surprisingly) face somewhat less regulatory activity. Plants in areas with high unemployment rates generate more air pollution and less water pollution, and face more air enforcement actions. The time trends are mostly unremarkable. The base year is 1985 (during 
the Reagan administration) except for the water pollution quantity equations which use a base year of 1989 (during the Bush administration). We see significantly higher regulatory activity and lower pollution quantities during the Clinton administration (except for water inspections, which are significantly lower).

Now consider the benefits-related variables that are the focus of our analysis. The marginal benefits per unit of pollution abatement for the overall population are associated with lower pollution levels (significant for all pollutants except for sulfur dioxide), but are surprisingly associated with significantly less air regulatory activity. The sensitive population groups (KIDS and ELDERS) are significantly negatively related to air pollution quantities, but also fewer air regulatory actions. Since the dependent variables are measured in log form, the coefficients reflect percentage impacts on pollution. For example, a one standard deviation increase in ELDERS (.019) is associated with 27 percent lower SO2 pollution and 19 percent lower particulate pollution; the comparable reductions for KIDS (.006) are 27 percent and 10 percent. On the air side, a one standard deviation increase in pollution abatement benefits (1.3 in $\operatorname{logs}$ ) is associated with 18 percent lower particulate emissions and 20 percent lower sulfur dioxide emissions. On the water side, the results (for a 2.0 increase in log benefits) show 11 percent lower BOD and 14 percent lower TSS.

The results for the "Environmental Justice" variables are mixed. POOR has the expected effects in most cases: significantly more air and water pollution, and fewer enforcement actions (although unexpectedly more inspections). However, the NONWHITE coefficient is always opposite in sign from POOR, and usually significant. It appears that nonwhites are not being discriminated against by regulators, although the poor may be.

Plants which are located in areas of high political activity and high support for 
environmental regulation, as measured by TURNOUT*CONVMEMB, are expected to face more regulatory activity and have less pollution. Pollution levels are significantly lower as expected, although the greater relative magnitude of the TURNOUT coefficient for the water pollution models means that the net effect of greater TURNOUT is more pollution for all but relatively high CONVMEMB states. The regulatory activity results are unexpected, as states with high turnout and above-average CONVMEMB values are associated with less, rather than more, regulatory activity for all but air enforcement actions.

The border effects in Tables 2 and 3 do not follow the expected pattern. Plants which are located near state borders show no significant differences in water pollution and lower particulate pollution, and there is more air pollution where the bordering states are stronger environmentally. ${ }^{5}$ The results for Canadian plants suggest different impacts for different pollutants. On the water pollution side we observe more BOD pollution and less regulatory activity. On the air pollution side we observe less SO2 pollution and more enforcement actions. This discrepancy across pollution media suggests that it might be valuable to examine the mechanisms for regulatory cooperation between the US and Canada more closely.

Tables 4 and 5 present the results when the various population characteristics are interacted with the benefits from pollution abatement, to test for differences across groups in the 'weight' given their benefits when determining regulatory stringency. These results are similar to those in Tables 2 and 3 for the different population characteristics. We see greater benefits being associated with lower pollution levels at plants with low values of POOR and high values of KIDS, ELDERS and (surprisingly) NONWHITE. Because of the large negative effects of the

\footnotetext{
${ }^{5}$ This is due at least in part to the use of 50 mile circles to define being near a state border - most of our plants are near a state border by this definition. Earlier analyses using a 5 mile circle to define state borders find significantly greater pollution at border plants, and lower pollution when those border states are stronger environmentally.
} 
interactions with KIDS and ELDERS the non-interacted AIRBEN coefficient becomes positive, but when we evaluate the overall AIRBEN effect at the mean values of the various interactions we still get a negative impact of -0.14 on particulates and -0.15 on sulfur dioxide. The comparable numbers for WATBEN are -0.13 for TSS and -0.19 for BOD.

More importantly, we now get the expected results for the state border variables. Plants near other states have more pollution, but this effect is reduced when the neighboring state is stronger environmentally. How large are these effects? Recall that the overall impact of AIRBEN on sulfur dioxide was -0.15 . The AIRBENOUT coefficient of 0.263 combined with the AIRBENOUT*VOTE coefficient of -0.003 evaluated at the mean GREENVOTE of 54 reduces this effect to -0.05 , indicating that benefits outside the state have only one-third the impact of within-state benefits. Changes in the neighboring state's GREENVOTE from one standard deviation below average to one standard deviation above average (from 36 to 72 ) change this effect from +0.005 to -0.10 , a shift of about two-thirds of the in-state benefits. The impacts for other pollutants are similar, with benefits to people in high-GREENVOTE border states having nearly as great an impact as people in the plant's own state, while people in lowGREENVOTE border states count substantially less (except for particulates, where the interaction term is small). As before, the regulatory activity equations are less consistent with the model, with more air regulatory activity being faced by plants with benefits outside the state. The Canadian border effects are similar to those in the earlier models.

We can also try to quantify the impact of changes in demographics around a plant using the coefficients in Tables 4 and 5. For sulfur dioxide, a one standard deviation increase in ELDERS increases the impact of benefits by about one-third, from -0.15 to -0.21 (for KIDS it increases the impact to -0.20); a comparable increase in POOR reduces the impact of benefits by 
about one-quarter, to -0.11 . There is some variation in impact across pollutants, less on particulates and more on water pollutants, but overall the results show substantial impacts of the demographics around a plant on the responsiveness of our environmental measures to the marginal benefits of abatement.

Given that each model is being estimated for eight different equations (four air and water pollutants, along with inspections and enforcement equations), one might wonder whether the unobserved factors influencing each equation are correlated. To test this, we calculated the residuals for each of the 8 equations in Tables 4 and 5, and checked the correlations among these equations. The results are presented in Table 6. The only large correlations come for pollutants, where plants with surprisingly high emissions of one pollutant also tend to emit surprisingly large amounts of the other pollutant in that same media. These values are quite high, with correlations of about 0.8 between BOD and TSS discharges and 0.55 between particulates and sulfur dioxide emissions. Correlations between air and water pollutants are on the order of .1 to .2 , and correlations among the different measures of regulatory activity tend to be .1 or less.

One issue for interpreting our results is the possibility that certain population characteristics may be endogenous - driven by people sorting themselves between locations based on the pollution in those areas, rather than the pollution levels at plants being driven by regulatory pressures which depend on the population characteristics. Wolverton (2002) deals with the sorting issue by examining a set of plants that are relatively young, and including population characteristics from before the plants began operations. Unfortunately for our analysis, most paper mills are quite old (only $25 \%$ of our plants started operations after 1960 , and very few started after 1980). In any event, population data at a detailed geographic level for non-urban areas are first available in the 1990 Census of Population, and that's what we use 
here.

Tables 7 and 8 present the results from an alternative analysis, focusing on the results for the POOR variable. The poor are arguably the ones most likely to have their location decisions driven by pollution characteristics, if greater pollution reduces housing values and attracts more poor residents. Suppose that areas around plants differed in terms of the mobility of the population, for reasons other than pollution levels. In the areas where the population moves more often there will be more opportunity for endogenous sorting to occur. SORTING is the fraction of the population near the plant in 1990 which had moved there since 1985 . We interact SORTING with POOR, and expect to see positive coefficients on POOR*SORTING in the pollution level equations if sorting matters. We do find a significant positive coefficient for one of the four pollution equations (particulates), but significant negative coefficients for both of the water pollution results (and insignificant positive results for $\mathrm{SO}_{2}$ ). These results suggest that the positive POOR coefficients found for all four pollutants in the earlier tables are not primarily due to bias caused by endogenous sorting.

\section{CONCLUSIONS AND POSSIBLE EXTENSIONS}

In this paper we use a plant-level panel data set on approximately 300 pulp and paper mills from 1985-1997 to examine the allocation of environmental regulation across plants. We focus on the benefit side of the $\mathrm{MB}=\mathrm{MC}$ equation, and find that plants in areas with higher marginal benefits of pollution abatement have lower pollution levels. Demographics also matter, as plants with more kids, more elders, and fewer poor people nearby emit less pollution. Plants near state boundaries emit more pollution, with these boundary effects reduced if the bordering states have more pro-environment Congressional delegations. Plants in areas with politically 
active populations that are also environmentally conscious emit less pollution.

Not every result fits the predictions of our model. The percentage nonwhite near the plant, expected to reduce regulatory attention in the Environmental Justice model, is actually associated with more regulatory activity and lower emissions. The results for the regulatory activity equations are generally less consistent with our hypotheses than those for the emissions equations. Perhaps regulators use other, unmeasured, mechanisms to control emissions levels, such as the details of the air and water permit requirements for each plant. Still, the significant results for the air pollution emissions and water pollution discharges suggest an important role for these benefit-side factors in determining the environmental regulation faced by different plants.

One important caveat on the results is the cross-sectional nature of our demographic data. Some of our results could be explained as reverse causation or sorting: poor people move towards dirty neighborhoods because housing is cheaper there; families with sensitive individuals such as kids and elders avoid dirty neighborhoods. It is difficult for us to control for such endogeneity because most paper mills are very old, so we cannot include pre-siting demographics in the analysis. Our attempt to test for sorting (using the degree of population turnover near the plant) finds significant evidence in favor of sorting for only one of the four pollutants (particulates), while the two water pollutants find significant evidence against sorting.

On the positive side, some of the differences in results for different regulatory measures pose further research questions. There is a pattern of unexpected signs for regulatory activity, where factors associated with less regulatory activity are often associated with less pollution, when we expected opposite signs on these coefficients. Is this an artifact of the data, or does it 
represent a real difference in the process by which regulatory activity is allocated in different situations? Similarly, do the different effects on air and water pollution of being near the Canadian border reflect real differences across pollution media in the mechanisms for ensuring international cooperation on pollution control?

Potential extensions of this project include a more detailed examination of these border effects and the differences between air and water pollution regulation. We plan to distinguish between state and federal enforcement and to explore other ways to more accurately measure the political activism of a community. We will test whether a plant's pollution abatement spending is also affected by the benefits of pollution abatement. Finally, we will examine the results for other industries, to see whether our results for the paper industry hold up in other settings. 


\section{REFERENCES}

S. Arora and T. N.Cason, "Do Community Characteristics Influence Environmental Outcomes? Evidence from the Toxic Release Inventory”, Southern Economic Journal 65, 691-716 (1999).

V. Been, "Locally Undesirable Land Uses in Minority Neighborhoods: Disproportionate Siting or Market Dynamics," The Yale Law Journal 103, 1383-1421 (1994).

V. Been and F. Gupta, "Coming to a Nuisance or Going to a Barrios? A Longitudinal Analysis of Environmental Justice Claims," Ecology Law Quaterly 24, 1-56 (1997).

R.T. Carson and R.C. Mitchell, "The Value of Clean Water: The Public's Willingness to Pay for Boatable, Fishable, and Swimmable Quality Water," Water Resources Research 29, 2445-2454 (1993).

Council of State Governments, "Resource Guide to State Environmental Management," Lexington, Kentucky (1991).

M. E. Deily and W. B. Gray, Enforcement of Pollution Regulations in a Declining Industry, Journal of Environmental Economics and Management 21, 260-274 (1991).

W. B. Gray and R. J. Shadbegian, "When is Enforcement Effective -- or Even Necessary?, presented at the Association of Environmental and Natural Resource Economists (June 2000), NBER Summer Institute (August 2000).

W. B. Gray and R. J. Shadbegian, "What Determines the Environmental Performance of Paper Mills? The Roles of Abatement Spending, Regulation, and Efficiency," presented at the American Economic Association Meetings (January 2001) and the Western Economic Association Meetings (July 2001).

R. Hall and M. L. Kerr, “Green Index: A State-by-State Guide to the Nation's Environmental Health," Island Press, Washington, D.C. (1991).

J. Hamilton, Politics and Social Costs: Estimating the Impact of Collective Action on Hazardous Waste Facilities, Rand Journal of Economics 24, 101-125 (1993).

J. Hamilton, Testing for Environmental Racism: Prejudice, Profits, Political Power?, Journal of Policy Analysis and Management 14, 107-132 (1995).

E. Helland and A. B. Whiford, "Pollution Incidence and Political Jurisdiction: Evidence from the TRI," presented at the American Economic Association Meetings (January 2001) and the Western Economic Association Meetings (July 2001). 


\section{REFERENCES (cont.)}

R. Jenkins, K. Maguire and C. Morgan, "Host Community Compensation and Municipal Solid Waste Landfills," U.S. Environmental Protection Agency, National Center for Environmental Economics mimeo (2002).

M. E. Kahn, The Silver Lining of Rust Belt Manufacturing Decline, Journal of Urban Economics 46, pp. 360-376 (1999).

W. Kreisel, T. J. Centner, and A. G. Keeler, Neighborhood Exposure to Toxic Releases: Are Their Racial Inequities?, Growth and Change 27. 479-499 (1996).

W. A. Magat and W. K. Viscusi, Effectiveness of the EPA's Regulatory Enforcement: The Case of Industrial Effluent Standards, Journal of Law and Economics 33, 331-360 (1990).

L. W. Nadeau, EPA Effectiveness at Reducing the Duration of Plant-Level Noncompliance, Journal of Environmental Economics and Management 34, 54-78 (1997).

Mancur Olson, “The Logic of Collective Action," Harvard University Press, Cambridge, MA (1965).

R. J. Shadbegian, W. B. Gray, and J. Levy, "Spatial Efficiency of Pollution Abatement Expenditures," presented Harvard University's Kennedy School of Government's Lecture Series on Environmental Economics (March 2000) and at NBER Environmental Economics session (April 2000).

A. Wolverton, "Race Does Not Matter: An Examination of a Polluting Plant's Location Decision," U.S. Environmental Protection Agency, National Center for Environmental Economics mimeo (2002). 
TABLE 1

DESCRIPTIVE STATISTICS
$(\mathrm{N}=4032$, air enforcement dataset, unless otherwise noted)

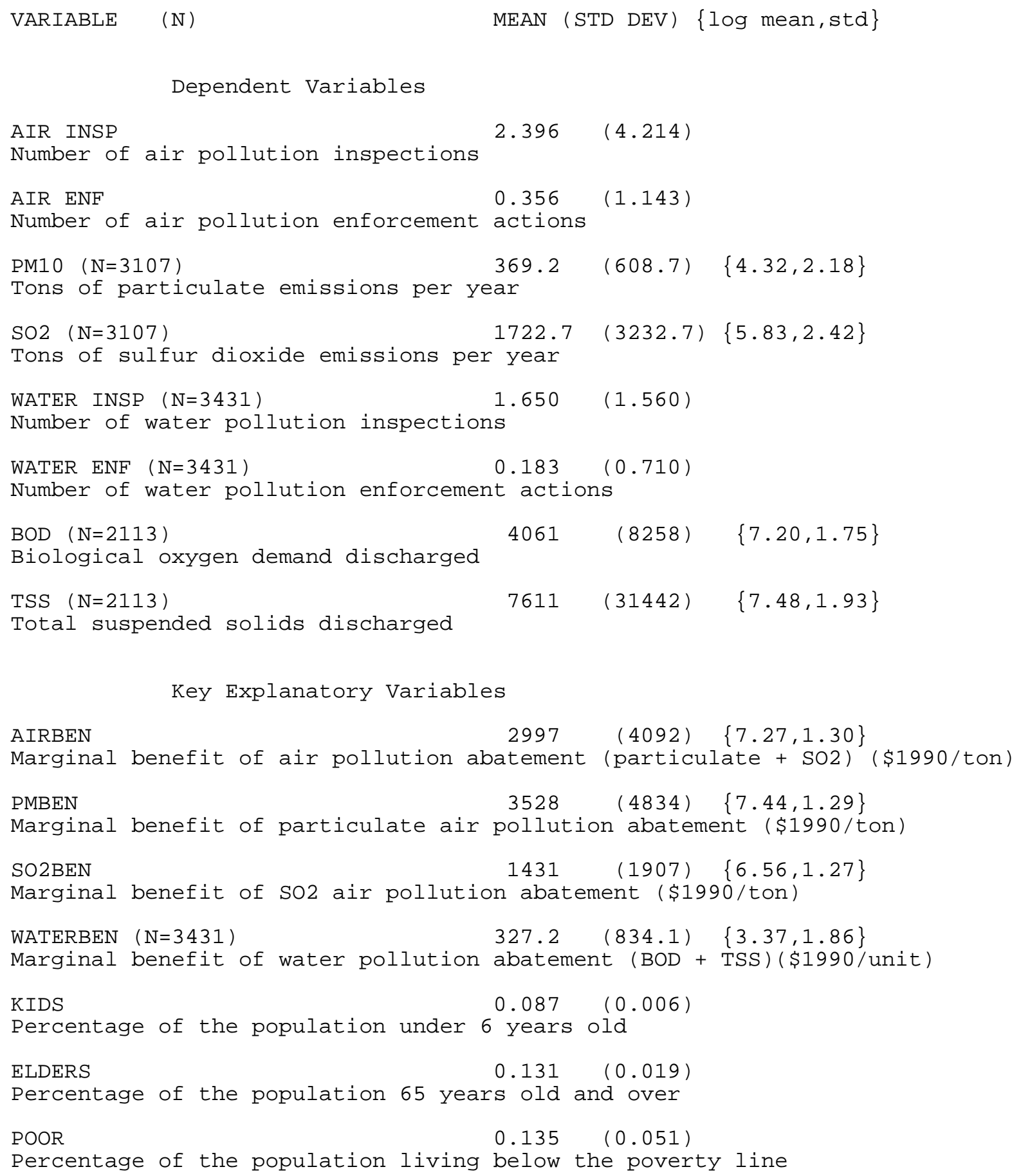


Table 1 (cont.)

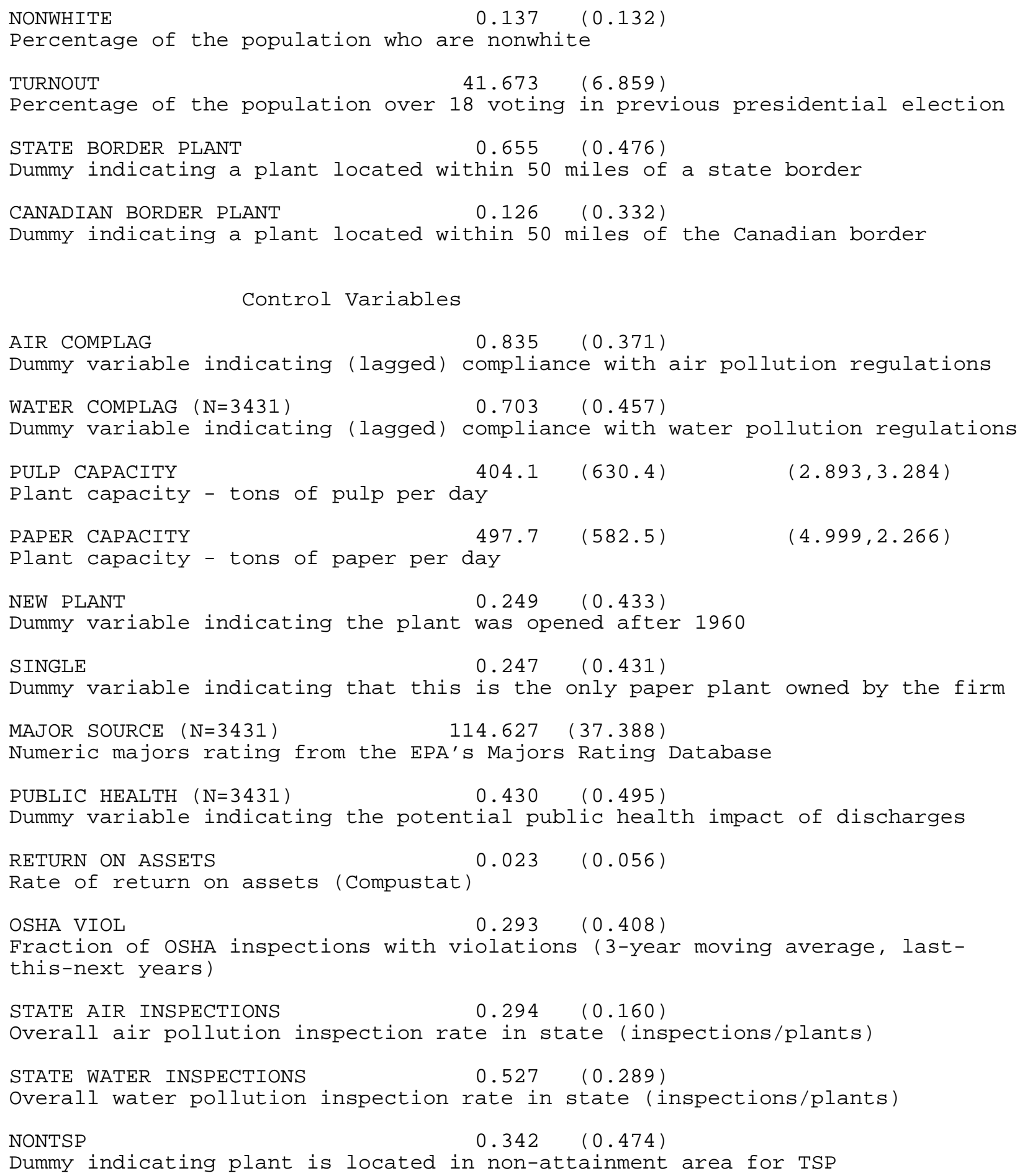




\section{Table 1 (cont.)}

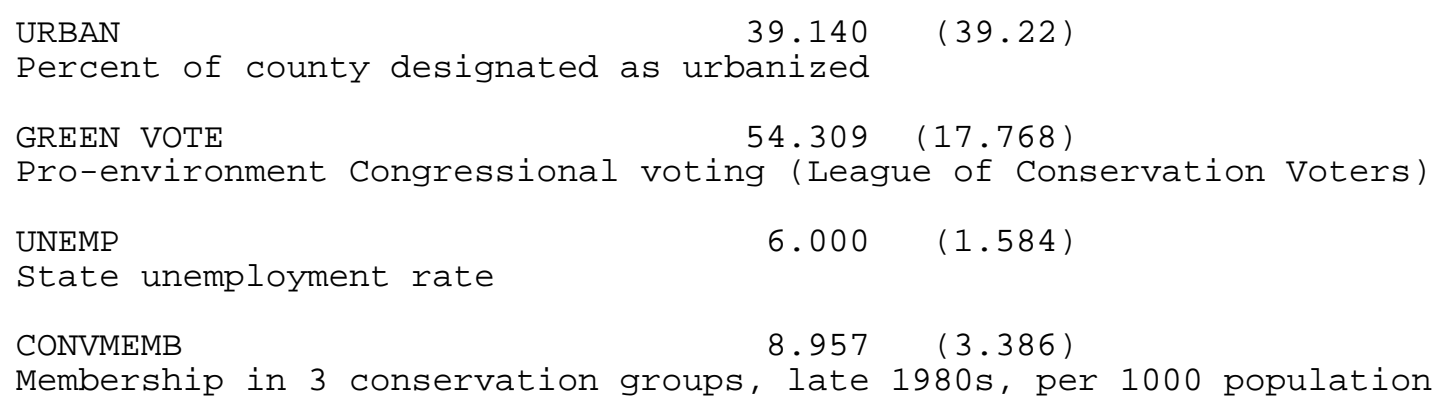


TABLE 2

BASIC AIR MODEL

\begin{tabular}{|c|c|c|c|c|}
\hline _DEPVAR & AIR INSP & AIR ENF & PM10 & $\mathrm{SO} 2$ \\
\hline _NOBS & 4032 & 4032 & 3107 & 3107 \\
\hline AIRBEN & $\begin{array}{l}-0.101 \\
(-3.360)\end{array}$ & $\begin{array}{c}-0.313 \\
(-3.780)\end{array}$ & $\begin{array}{c}-0.169 \\
(-4.120)\end{array}$ & $\begin{array}{l}-0.060 \\
(-1.200)\end{array}$ \\
\hline ELDERS & $\begin{array}{l}-4.091 \\
(-2.300)\end{array}$ & $\begin{array}{l}8.643 \\
(1.720)\end{array}$ & $\begin{array}{l}-9.945 \\
(-3.750)\end{array}$ & $\begin{array}{l}-14.028 \\
(-3.940)\end{array}$ \\
\hline KIDS & $\begin{array}{l}-11.646 \\
(-2.260)\end{array}$ & $\begin{array}{c}-0.747 \\
(-0.050)\end{array}$ & $\begin{array}{l}-16.710 \\
(-2.430)\end{array}$ & $\begin{array}{l}-45.774 \\
(-4.770)\end{array}$ \\
\hline POOR & $\begin{array}{l}-0.506 \\
(-0.570)\end{array}$ & $\begin{array}{l}-10.456 \\
(-4.340)\end{array}$ & $\begin{array}{l}2.426 \\
(2.040)\end{array}$ & $\begin{array}{l}5.002 \\
(2.920)\end{array}$ \\
\hline NONWH I TE & $\begin{array}{c}0.557 \\
(1.670)\end{array}$ & $\begin{array}{c}2.712 \\
(3.230)\end{array}$ & $\begin{array}{l}-1.136 \\
(-2.720)\end{array}$ & $\begin{array}{l}-3.184 \\
(-5.170)\end{array}$ \\
\hline $\begin{array}{l}\text { STATE } \\
\text { BORDER }\end{array}$ & $\begin{array}{c}-0.098 \\
(-0.990)\end{array}$ & $\begin{array}{c}-0.589 \\
(-1.910)\end{array}$ & $\begin{array}{c}-0.452 \\
(-3.090)\end{array}$ & $\begin{array}{l}-0.087 \\
(-0.420)\end{array}$ \\
\hline $\begin{array}{l}\text { STATE BORDER } \\
\text { * GREEN VOTE }\end{array}$ & $\begin{array}{c}0.003 \\
(1.840)\end{array}$ & $\begin{array}{c}0.013 \\
(2.380)\end{array}$ & $\begin{array}{c}0.008 \\
(3.190)\end{array}$ & $\begin{array}{c}0.005 \\
(1.540)\end{array}$ \\
\hline $\begin{array}{l}\text { CANAD IAN } \\
\text { BORDER }\end{array}$ & $\begin{array}{c}0.004 \\
(0.060)\end{array}$ & $\begin{array}{c}0.542 \\
(2.990)\end{array}$ & $\begin{array}{c}0.093 \\
(0.860)\end{array}$ & $\begin{array}{c}-0.533 \\
(-3.940)\end{array}$ \\
\hline TURNOUT & $\begin{array}{c}0.169 \\
(0.420)\end{array}$ & $\begin{array}{c}-1.279 \\
(-1.160)\end{array}$ & $\begin{array}{c}0.737 \\
(1.190)\end{array}$ & $\begin{array}{c}1.512 \\
(1.750)\end{array}$ \\
\hline $\begin{array}{l}\text { TURNOUT * } \\
\text { CONVMEMB }\end{array}$ & $\begin{array}{l}-0.053 \\
(-1.690)\end{array}$ & $\begin{array}{c}0.193 \\
(2.420)\end{array}$ & $\begin{array}{c}-0.217 \\
(-5.700)\end{array}$ & $\begin{array}{l}-0.227 \\
(-4.300)\end{array}$ \\
\hline \multicolumn{5}{|c|}{ Control Variables } \\
\hline AIR COMPLAG & $\begin{array}{c}-0.323 \\
(-6.880)\end{array}$ & $\begin{array}{l}-0.943 \\
(-8.680)\end{array}$ & $\begin{array}{l}-0.583 \\
(-7.340)\end{array}$ & $\begin{array}{l}-0.849 \\
(-8.640)\end{array}$ \\
\hline $\begin{array}{l}\text { PULP } \\
\text { CAPACITY }\end{array}$ & $\begin{array}{c}0.117 \\
(15.500)\end{array}$ & $\begin{array}{l}0.199 \\
(9.130)\end{array}$ & $\begin{array}{c}0.348 \\
(25.380)\end{array}$ & $\begin{array}{c}0.307 \\
(17.760)\end{array}$ \\
\hline $\begin{array}{l}\text { PAPER } \\
\text { CAPACITY }\end{array}$ & $\begin{array}{l}-0.009 \\
(-1.020)\end{array}$ & $\begin{array}{c}-0.031 \\
(-1.370)\end{array}$ & $\begin{array}{l}-0.026 \\
(-2.060)\end{array}$ & $\begin{array}{c}0.033 \\
(2.010)\end{array}$ \\
\hline NEW PLANT & $\begin{array}{l}-0.046 \\
(-1.140)\end{array}$ & $\begin{array}{c}0.172 \\
(1.590)\end{array}$ & $\begin{array}{c}0.243 \\
(3.990)\end{array}$ & $\begin{array}{c}0.140 \\
(1.620)\end{array}$ \\
\hline SINGLE & $\begin{array}{c}-0.089 \\
(-2.050)\end{array}$ & $\begin{array}{c}-0.236 \\
(-1.830)\end{array}$ & $\begin{array}{c}-0.249 \\
(-3.810)\end{array}$ & $\begin{array}{c}-0.083 \\
(-0.920)\end{array}$ \\
\hline $\begin{array}{l}\text { RETURN ON } \\
\text { ASSSETS }\end{array}$ & $\begin{array}{c}0.562 \\
(2.120)\end{array}$ & $\begin{array}{l}-0.185 \\
(-0.220)\end{array}$ & $\begin{array}{l}1.679 \\
(1.850)\end{array}$ & $\begin{array}{c}1.809 \\
(1.620)\end{array}$ \\
\hline $\begin{array}{l}\text { OSHA } \\
\text { VIOL }\end{array}$ & $\begin{array}{l}-0.003 \\
(-0.060)\end{array}$ & $\begin{array}{l}0.597 \\
(3.610)\end{array}$ & $\begin{array}{l}0.004 \\
(0.050)\end{array}$ & $\begin{array}{l}-0.271 \\
(-2.430)\end{array}$ \\
\hline $\begin{array}{l}\text { STATE AIR } \\
\text { INSPECTIONS }\end{array}$ & $\begin{array}{c}2.150 \\
(19.790)\end{array}$ & $\begin{array}{l}-0.029 \\
(-0.230)\end{array}$ & $\begin{array}{l}-0.039 \\
(-0.510)\end{array}$ & $\begin{array}{l}-0.079 \\
(-0.810)\end{array}$ \\
\hline
\end{tabular}


TABLE 2

BASIC AIR MODEL (cont.)

\begin{tabular}{|c|c|c|c|c|}
\hline _DEPVAR & AIR INSP & AIR ENF & PM10 & $\mathrm{SO} 2$ \\
\hline NONTSP & $\begin{array}{c}0.037 \\
(0.830)\end{array}$ & $\begin{array}{c}-0.029 \\
(-0.230)\end{array}$ & $\begin{array}{c}-0.039 \\
(-0.510)\end{array}$ & $\begin{array}{c}-0.079 \\
(-0.810)\end{array}$ \\
\hline URBAN & $\begin{array}{l}-0.001 \\
(-2.320)\end{array}$ & $\begin{array}{c}0.002 \\
(1.260)\end{array}$ & $\begin{array}{l}-0.002 \\
(-2.980)\end{array}$ & $\begin{array}{c}-0.005 \\
(-4.460)\end{array}$ \\
\hline GREEN VOTE & $\begin{array}{c}0.000 \\
(0.130)\end{array}$ & $\begin{array}{l}-0.015 \\
(-2.640)\end{array}$ & $\begin{array}{l}-0.007 \\
(-2.290)\end{array}$ & $\begin{array}{c}0.003 \\
(0.770)\end{array}$ \\
\hline UNEMP & $\begin{array}{c}0.011 \\
(0.700)\end{array}$ & $\begin{array}{c}0.181 \\
(3.410)\end{array}$ & $\begin{array}{c}0.039 \\
(1.730)\end{array}$ & $\begin{array}{c}0.085 \\
(2.840)\end{array}$ \\
\hline YR8 6 & $\begin{array}{c}0.168 \\
(2.100)\end{array}$ & $\begin{array}{c}1.199 \\
(3.060)\end{array}$ & $\begin{array}{l}-0.007 \\
(-0.050)\end{array}$ & $\begin{array}{c}0.010 \\
(0.060)\end{array}$ \\
\hline YR87 & $\begin{array}{c}0.125 \\
(1.570)\end{array}$ & $\begin{array}{c}1.700 \\
(4.640)\end{array}$ & $\begin{array}{l}-0.044 \\
(-0.310)\end{array}$ & $\begin{array}{l}-0.012 \\
(-0.070)\end{array}$ \\
\hline YR88 & $\begin{array}{c}0.178 \\
(1.980)\end{array}$ & $\begin{array}{c}2.012 \\
(5.330)\end{array}$ & $\begin{array}{l}-0.086 \\
(-0.600)\end{array}$ & $\begin{array}{c}0.049 \\
(0.280)\end{array}$ \\
\hline YR89 & $\begin{array}{c}0.075 \\
(0.860)\end{array}$ & $\begin{array}{c}2.254 \\
(5.900)\end{array}$ & $\begin{array}{l}-0.052 \\
(-0.370)\end{array}$ & $\begin{array}{c}0.016 \\
(0.090)\end{array}$ \\
\hline YR90 & $\begin{array}{c}0.156 \\
(1.840)\end{array}$ & $\begin{array}{c}2.012 \\
(5.430)\end{array}$ & $\begin{array}{l}-0.263 \\
(-1.910)\end{array}$ & $\begin{array}{c}-0.191 \\
(-1.130)\end{array}$ \\
\hline YR91 & $\begin{array}{c}0.070 \\
(0.860)\end{array}$ & $\begin{array}{c}1.603 \\
(4.380)\end{array}$ & $\begin{array}{l}-0.436 \\
(-3.390)\end{array}$ & $\begin{array}{c}-0.298 \\
(-1.830)\end{array}$ \\
\hline YR92 & $\begin{array}{c}0.262 \\
(3.120)\end{array}$ & $\begin{array}{c}1.624 \\
(4.500)\end{array}$ & $\begin{array}{l}-0.396 \\
(-2.980)\end{array}$ & $\begin{array}{c}-0.382 \\
(-2.230)\end{array}$ \\
\hline YR93 & $\begin{array}{c}0.258 \\
(3.090)\end{array}$ & $\begin{array}{c}2.194 \\
(6.150)\end{array}$ & $\begin{array}{c}-0.314 \\
(-2.450)\end{array}$ & $\begin{array}{l}-0.514 \\
(-3.070)\end{array}$ \\
\hline YR94 & $\begin{array}{c}0.247 \\
(2.860)\end{array}$ & $\begin{array}{c}2.575 \\
(7.250)\end{array}$ & $\begin{array}{l}-0.284 \\
(-2.230)\end{array}$ & $\begin{array}{c}-0.425 \\
(-2.530)\end{array}$ \\
\hline YR95 & $\begin{array}{c}0.202 \\
(2.240)\end{array}$ & $\begin{array}{c}2.288 \\
(6.170)\end{array}$ & $\begin{array}{l}-0.341 \\
(-2.540)\end{array}$ & $\begin{array}{c}-0.451 \\
(-2.520)\end{array}$ \\
\hline YR96 & $\begin{array}{c}0.100 \\
(1.090)\end{array}$ & $\begin{array}{c}2.461 \\
(6.500)\end{array}$ & $\begin{array}{c}-0.622 \\
(-4.440)\end{array}$ & $\begin{array}{c}-0.620 \\
(-3.480)\end{array}$ \\
\hline YR97 & $\begin{array}{c}0.131 \\
(1.270)\end{array}$ & $\begin{array}{c}2.905 \\
(7.730)\end{array}$ & $\begin{array}{l}-0.553 \\
(-3.920)\end{array}$ & $\begin{array}{l}-0.621 \\
(-3.400)\end{array}$ \\
\hline _RSQUARE & 0.196 & 0.130 & 0.653 & 0.481 \\
\hline
\end{tabular}

T-statistics in parentheses. All regressions include state dummies.

AIRBEN row is PMBEN and SO2BEN for PM10 and SO2 models.

Regulatory activity models (INSP and ENF) use Negative Binomial model. Pollution quantity models use Log (pollution) in OLS model. 
TABLE 3

BASIC WATER MODEL

\begin{tabular}{|c|c|c|c|c|}
\hline _DEPVAR & NATER INSP & WATER ENE & TSS & $\mathrm{BOD}$ \\
\hline _NOBS & 3431 & 3431 & 2113 & 2113 \\
\hline WATERBEN & $\begin{array}{c}0.003 \\
(0.370)\end{array}$ & $\begin{array}{c}0.036 \\
(1.060)\end{array}$ & $\begin{array}{l}-0.076 \\
(-5.080)\end{array}$ & $\begin{array}{l}-0.123 \\
(-8.610)\end{array}$ \\
\hline POOR & $\begin{array}{c}1.538 \\
(2.790)\end{array}$ & $\begin{array}{l}-1 \cdot 915 \\
(-0.840)\end{array}$ & $\begin{array}{l}5.258 \\
(4.300)\end{array}$ & $\begin{array}{c}6.287 \\
(5.340)\end{array}$ \\
\hline NONWHITE & $\begin{array}{l}-1.048 \\
(-3.550)\end{array}$ & $\begin{array}{l}1.862 \\
(1.880)\end{array}$ & $\begin{array}{l}-3.866 \\
(-6.230)\end{array}$ & $\begin{array}{l}-3.516 \\
(-5.870)\end{array}$ \\
\hline $\begin{array}{l}\text { STATE } \\
\text { BORDER }\end{array}$ & $\begin{array}{c}-0.014 \\
(-0.170)\end{array}$ & $\begin{array}{c}-0.162 \\
(-0.520)\end{array}$ & $\begin{array}{c}0.122 \\
(0.830)\end{array}$ & $\begin{array}{c}0.061 \\
(0.420)\end{array}$ \\
\hline $\begin{array}{l}\text { STATE BORDER } \\
\text { *GREEN VOTE }\end{array}$ & $\begin{array}{l}-0.001 \\
(-0.390)\end{array}$ & $\begin{array}{c}0.003 \\
(0.590)\end{array}$ & $\begin{array}{c}0.000 \\
(0.000)\end{array}$ & $\begin{array}{c}0.001 \\
(0.270)\end{array}$ \\
\hline $\begin{array}{l}\text { CANAD IAN } \\
\text { BORDER }\end{array}$ & $\begin{array}{l}-0.079 \\
(-1.510)\end{array}$ & $\begin{array}{c}-0.192 \\
(-1.050)\end{array}$ & $\begin{array}{c}0.061 \\
(0.570)\end{array}$ & $\begin{array}{c}0.431 \\
(4.430)\end{array}$ \\
\hline TURNOUT & $\begin{array}{l}1.324 \\
(3.990)\end{array}$ & $\begin{array}{l}2.332 \\
(1.420)\end{array}$ & $\begin{array}{l}3.294 \\
(4.620)\end{array}$ & $\begin{array}{c}4.686 \\
(6.700)\end{array}$ \\
\hline $\begin{array}{l}\text { TURNOUT * } \\
\text { CONVMEMB }\end{array}$ & $\begin{array}{l}-0.071 \\
(-2.850)\end{array}$ & $\begin{array}{l}-0.308 \\
(-1.880)\end{array}$ & $\begin{array}{l}-0.313 \\
(-4.870)\end{array}$ & $\begin{array}{l}-0.354 \\
(-5.410)\end{array}$ \\
\hline \multicolumn{5}{|c|}{ Control Variables } \\
\hline WATER COMPLAG & $\begin{array}{l}-0.054 \\
(-1.800)\end{array}$ & $\begin{array}{l}-0.018 \\
(-0.120)\end{array}$ & $\begin{array}{l}-0.021 \\
(-0.330)\end{array}$ & $\begin{array}{l}0.004 \\
(0.070)\end{array}$ \\
\hline MAJORS & $\begin{array}{l}0.004 \\
(9.850)\end{array}$ & $\begin{array}{c}0.004 \\
(2.130)\end{array}$ & $\begin{array}{l}0.014 \\
(9.680)\end{array}$ & $\begin{array}{c}0.012 \\
(8.960)\end{array}$ \\
\hline $\begin{array}{l}\text { PUBLIC } \\
\text { HEALTH }\end{array}$ & $\begin{array}{c}0.074 \\
(2.190)\end{array}$ & $\begin{array}{c}0.218 \\
(1.630)\end{array}$ & $\begin{array}{l}-0.003 \\
(-0.040)\end{array}$ & $\begin{array}{c}0.081 \\
(1.080)\end{array}$ \\
\hline $\begin{array}{l}\text { PULP } \\
\text { CAPACITY }\end{array}$ & $\begin{array}{l}-0.010 \\
(-1.650)\end{array}$ & $\begin{array}{c}0.053 \\
(2.050)\end{array}$ & $\begin{array}{c}0.219 \\
(17.000)\end{array}$ & $\begin{array}{c}0.186 \\
(14.120)\end{array}$ \\
\hline $\begin{array}{l}\text { PAPER } \\
\text { CAPACITY }\end{array}$ & $\begin{array}{c}0.001 \\
(0.200)\end{array}$ & $\begin{array}{c}0.013 \\
(0.390)\end{array}$ & $\begin{array}{l}-0.049 \\
(-3.970)\end{array}$ & $\begin{array}{l}-0.050 \\
(-4.340)\end{array}$ \\
\hline NEW PLANT & $\begin{array}{c}-0.014 \\
(-0.440)\end{array}$ & $\begin{array}{l}-0.327 \\
(-2.130)\end{array}$ & $\begin{array}{l}0.102 \\
(1.550)\end{array}$ & $\begin{array}{c}0.029 \\
(0.440)\end{array}$ \\
\hline SINGLE & $\begin{array}{c}0.010 \\
(0.260)\end{array}$ & $\begin{array}{c}0.412 \\
(2.660)\end{array}$ & $\begin{array}{l}-0.222 \\
(-2.790)\end{array}$ & $\begin{array}{c}0.047 \\
(0.600)\end{array}$ \\
\hline $\begin{array}{l}\text { RETURN ON } \\
\text { ASSETS }\end{array}$ & $\begin{array}{l}-0.061 \\
(-0.400)\end{array}$ & $\begin{array}{l}1.210 \\
(0.960)\end{array}$ & $\begin{array}{l}-0.306 \\
(-1.140)\end{array}$ & $\begin{array}{l}-0.307 \\
(-1.560)\end{array}$ \\
\hline $\begin{array}{l}\text { OSHA } \\
\text { VIOL }\end{array}$ & $\begin{array}{l}-0.016 \\
(-0.370)\end{array}$ & $\begin{array}{c}0.321 \\
(1.720)\end{array}$ & $\begin{array}{l}-0.130 \\
(-1.510)\end{array}$ & $\begin{array}{l}-0.109 \\
(-1.330)\end{array}$ \\
\hline $\begin{array}{l}\text { STATE WATER } \\
\text { INSPECTIONS }\end{array}$ & $\begin{array}{c}1.730 \\
(13.810)\end{array}$ & $\begin{array}{c}0.237 \\
(0.440)\end{array}$ & $\begin{array}{l}-0.318 \\
(-1.470)\end{array}$ & $\begin{array}{l}-0.259 \\
(-1.190)\end{array}$ \\
\hline
\end{tabular}


TABLE 3

BASIC WATER MODEL (cont.)

\begin{tabular}{|c|c|c|c|c|}
\hline _DEPVAR & WATER INSP & WATER ENF & TSS & $\mathrm{BOD}$ \\
\hline URBAN & $\begin{array}{l}-0.000 \\
(-0.200)\end{array}$ & $\begin{array}{c}-0.004 \\
(-2.150)\end{array}$ & $\begin{array}{l}-0.002 \\
(-2.080)\end{array}$ & $\begin{array}{c}-0.002 \\
(-1.790)\end{array}$ \\
\hline GREEN VOTE & $\begin{array}{c}0.000 \\
(0.180)\end{array}$ & $\begin{array}{c}0.005 \\
(0.620)\end{array}$ & $\begin{array}{l}-0.004 \\
(-0.970)\end{array}$ & $\begin{array}{l}-0.002 \\
(-0.430)\end{array}$ \\
\hline UNEMP & $\begin{array}{c}-0.004 \\
(-0.340)\end{array}$ & $\begin{array}{c}0.025 \\
(0.450)\end{array}$ & $\begin{array}{c}-0.137 \\
(-3.390)\end{array}$ & $\begin{array}{l}-0.155 \\
(-3.910)\end{array}$ \\
\hline YR8 6 & $\begin{array}{c}-0.019 \\
(-0.290)\end{array}$ & $\begin{array}{c}0.495 \\
(1.070)\end{array}$ & & \\
\hline YR87 & $\begin{array}{c}-0.186 \\
(-2.760)\end{array}$ & $\begin{array}{c}0.890 \\
(2.160)\end{array}$ & & \\
\hline YR8 8 & $\begin{array}{c}-0.033 \\
(-0.480)\end{array}$ & $\begin{array}{c}1.154 \\
(2.660)\end{array}$ & & \\
\hline YR89 & $\begin{array}{c}-0.065 \\
(-0.920)\end{array}$ & $\begin{array}{c}1.202 \\
(2.900)\end{array}$ & & \\
\hline YR90 & $\begin{array}{c}-0.133 \\
(-1.950)\end{array}$ & $\begin{array}{l}1.184 \\
(2.930)\end{array}$ & $\begin{array}{c}0.065 \\
(0.560)\end{array}$ & $\begin{array}{c}0.078 \\
(0.710)\end{array}$ \\
\hline YR91 & $\begin{array}{c}-0.165 \\
(-2.510)\end{array}$ & $\begin{array}{c}1.494 \\
(3.740)\end{array}$ & $\begin{array}{c}0.162 \\
(1.190)\end{array}$ & $\begin{array}{c}0.182 \\
(1.340)\end{array}$ \\
\hline YR92 & $\begin{array}{c}-0.309 \\
(-4.530)\end{array}$ & $\begin{array}{c}1.484 \\
(3.560)\end{array}$ & $\begin{array}{c}0.039 \\
(0.260)\end{array}$ & $\begin{array}{c}0.096 \\
(0.680)\end{array}$ \\
\hline YR93 & $\begin{array}{c}-0.381 \\
(-5.600)\end{array}$ & $\begin{array}{c}0.804 \\
(2.040)\end{array}$ & $\begin{array}{c}0.018 \\
(0.140)\end{array}$ & $\begin{array}{c}-0.017 \\
(-0.140)\end{array}$ \\
\hline YR94 & $\begin{array}{l}-0.312 \\
(-4.640)\end{array}$ & $\begin{array}{c}1.207 \\
(3.020)\end{array}$ & $\begin{array}{l}-0.101 \\
(-0.790)\end{array}$ & $\begin{array}{c}-0.168 \\
(-1.380)\end{array}$ \\
\hline YR95 & $\begin{array}{c}-0.338 \\
(-4.590)\end{array}$ & $\begin{array}{c}0.970 \\
(2.300)\end{array}$ & $\begin{array}{l}-0.236 \\
(-1.820)\end{array}$ & $\begin{array}{c}-0.282 \\
(-2.210)\end{array}$ \\
\hline YR96 & $\begin{array}{c}-0.399 \\
(-5.240)\end{array}$ & $\begin{array}{c}0.736 \\
(1.730)\end{array}$ & $\begin{array}{l}-0.279 \\
(-2.190)\end{array}$ & $\begin{array}{c}-0.307 \\
(-2.420)\end{array}$ \\
\hline YR97 & $\begin{array}{c}-0.469 \\
(-6.160)\end{array}$ & $\begin{array}{c}0.649 \\
(1.430)\end{array}$ & $\begin{array}{l}-0.358 \\
(-2.800)\end{array}$ & $\begin{array}{c}-0.392 \\
(-3.040)\end{array}$ \\
\hline RSQUARE & 0.123 & 0.164 & 0.622 & 0.578 \\
\hline
\end{tabular}

T-statistics in parentheses. All regressions include state dummies.

Regulatory activity models (INSP and ENF) use Negative Binomial model. Pollution quantity models use Log (pollution) in OLS model. 
TABLE 4

EXTENDED AIR BENEFITS MODEL

\begin{tabular}{|c|c|c|c|c|}
\hline _DEPVAR & AIR INSP & AIR ENF & PM10 & $\mathrm{SO} 2$ \\
\hline _NOBS & 4032 & 4032 & 3107 & 3107 \\
\hline AIRBEN & $\begin{array}{c}0.147 \\
(1.820)\end{array}$ & $\begin{array}{l}-0.351 \\
(-1.400)\end{array}$ & $\begin{array}{c}0.014 \\
(0.120)\end{array}$ & $\begin{array}{c}1.034 \\
(5.800)\end{array}$ \\
\hline $\begin{array}{l}\text { AIRBEN* } \\
\text { OUT-STATE }\end{array}$ & $\begin{array}{c}0.006 \\
(0.210)\end{array}$ & $\begin{array}{c}-0.092 \\
(-1.080)\end{array}$ & $\begin{array}{c}0.061 \\
(1.310)\end{array}$ & $\begin{array}{c}0.263 \\
(3.710)\end{array}$ \\
\hline $\begin{array}{l}\text { AIRBEN* } \\
\text { OUT-STATE* } \\
\text { GREEN VOTE }\end{array}$ & $\begin{array}{c}0.001 \\
(1.210)\end{array}$ & $\begin{array}{c}0.003 \\
(1.970)\end{array}$ & $\begin{array}{c}-0.001 \\
(-1.170)\end{array}$ & $\begin{array}{c}-0.003 \\
(-2.220)\end{array}$ \\
\hline $\begin{array}{l}\text { AIRBEN* } \\
\text { ELDERS }\end{array}$ & $\begin{array}{c}-0.782 \\
(-2.980)\end{array}$ & $\begin{array}{l}1.396 \\
(1.800)\end{array}$ & $\begin{array}{c}-0.731 \\
(-1.870)\end{array}$ & $\begin{array}{l}-3.203 \\
(-5.290)\end{array}$ \\
\hline $\begin{array}{l}\text { AIRBEN* } \\
\text { KIDS }\end{array}$ & $\begin{array}{c}-1.862 \\
(-2.630)\end{array}$ & $\begin{array}{c}-0.149 \\
(-0.070)\end{array}$ & $\begin{array}{c}-0.923 \\
(-0.950)\end{array}$ & $\begin{array}{l}-9.011 \\
(-5.840)\end{array}$ \\
\hline $\begin{array}{l}\text { AIRBEN* } \\
\text { POOR }\end{array}$ & $\begin{array}{c}-0.031 \\
(-0.250)\end{array}$ & $\begin{array}{c}-1.539 \\
(-4.210)\end{array}$ & $\begin{array}{c}0.388 \\
(2.320)\end{array}$ & $\begin{array}{c}0.798 \\
(2.960)\end{array}$ \\
\hline $\begin{array}{l}\text { AIRBEN* } \\
\text { NONWHITE }\end{array}$ & $\begin{array}{c}0.081 \\
(1.940)\end{array}$ & $\begin{array}{c}0.370 \\
(3.150)\end{array}$ & $\begin{array}{c}-0.195 \\
(-3.510)\end{array}$ & $\begin{array}{l}-0.461 \\
(-5.000)\end{array}$ \\
\hline $\begin{array}{l}\text { CANAD IAN } \\
\text { BORDER }\end{array}$ & $\begin{array}{c}-0.014 \\
(-0.210)\end{array}$ & $\begin{array}{c}0.573 \\
(3.280)\end{array}$ & $\begin{array}{c}0.105 \\
(1.000)\end{array}$ & $\begin{array}{c}-0.547 \\
(-4.220)\end{array}$ \\
\hline TURNOUT & $\begin{array}{c}0.379 \\
(0.950)\end{array}$ & $\begin{array}{c}-1.107 \\
(-0.980)\end{array}$ & $\begin{array}{c}0.278 \\
(0.440)\end{array}$ & $\begin{array}{c}2.101 \\
(2.490)\end{array}$ \\
\hline $\begin{array}{l}\text { TURNOUT * } \\
\text { CONVMEMB }\end{array}$ & $\begin{array}{c}-0.059 \\
(-1.830)\end{array}$ & $\begin{array}{c}0.173 \\
(2.130)\end{array}$ & $\begin{array}{c}-0.159 \\
(-3.990)\end{array}$ & $\begin{array}{l}-0.196 \\
(-3.600)\end{array}$ \\
\hline _RSQUARE & 0.196 & 0.130 & 0.651 & 0.486 \\
\hline
\end{tabular}

T-statistics in parentheses. All regressions include state dummies. Models include all control variable from Table 2.

AIRBEN row is PMBEN and SO2BEN for PM1O and SO2 models.

Regulatory activity models (INSP and ENF) use Negative Binomial model. Pollution quantity models use Log(pollution) in OLS model. 
TABLE 5

EXTENDED WATER BENEFITS MODEL

\begin{tabular}{|c|c|c|c|c|}
\hline _DEPVAR & WATER INSP & WATER ENF & TSS & BOD \\
\hline _NOBS & 2134.00 & 2134.00 & 1362.00 & 1362.00 \\
\hline WATERBEN & $\begin{array}{l}-0.004 \\
(-0.180)\end{array}$ & $\begin{array}{c}0.104 \\
(1.200)\end{array}$ & $\begin{array}{l}-0.241 \\
(-5.330)\end{array}$ & $\begin{array}{l}-0.344 \\
(-8.040)\end{array}$ \\
\hline $\begin{array}{l}\text { WATERBEN* } \\
\text { OUT-STATE }\end{array}$ & $\begin{array}{c}-0.084 \\
(-2.840)\end{array}$ & $\begin{array}{c}0.108 \\
(1.050)\end{array}$ & $\begin{array}{c}0.158 \\
(2.960)\end{array}$ & $\begin{array}{c}0.249 \\
(4.810)\end{array}$ \\
\hline $\begin{array}{l}\text { WATERBEN * } \\
\text { OUT-STATE* } \\
\text { GREEN VOTE }\end{array}$ & $\begin{array}{c}0.001 \\
(2.280)\end{array}$ & $\begin{array}{l}-0.004 \\
(-1.620)\end{array}$ & $\begin{array}{l}-0.002 \\
(-2.990)\end{array}$ & $\begin{array}{c}-0.003 \\
(-3.730)\end{array}$ \\
\hline $\begin{array}{l}\text { WATERBEN* } \\
\text { POOR }\end{array}$ & $\begin{array}{c}0.004 \\
(0.030)\end{array}$ & $\begin{array}{c}-0.959 \\
(-1.580)\end{array}$ & $\begin{array}{c}0.962 \\
(3.140)\end{array}$ & $\begin{array}{c}1.516 \\
(4.770)\end{array}$ \\
\hline $\begin{array}{l}\text { WATERBEN* } \\
\text { NONWHITE }\end{array}$ & $\begin{array}{l}-0.070 \\
(-1.190)\end{array}$ & $\begin{array}{c}0.279 \\
(0.970)\end{array}$ & $\begin{array}{c}-0.107 \\
(-0.870)\end{array}$ & $\begin{array}{c}-0.334 \\
(-2.460)\end{array}$ \\
\hline $\begin{array}{l}\text { CANAD IAN } \\
\text { BORDER }\end{array}$ & $\begin{array}{l}-0.025 \\
(-0.440)\end{array}$ & $\begin{array}{c}-0.334 \\
(-1.480)\end{array}$ & $\begin{array}{c}0.050 \\
(0.480)\end{array}$ & $\begin{array}{c}0.439 \\
(4.830)\end{array}$ \\
\hline TURNOUT & $\begin{array}{l}1.410 \\
(3.840)\end{array}$ & $\begin{array}{c}3.551 \\
(1.900)\end{array}$ & $\begin{array}{c}4.813 \\
(6.410)\end{array}$ & $\begin{array}{l}6.309 \\
(8.030)\end{array}$ \\
\hline $\begin{array}{l}\text { TURNOUT * } \\
\text { CONVMEMB }\end{array}$ & $\begin{array}{c}-0.065 \\
(-2.610)\end{array}$ & $\begin{array}{c}-0.698 \\
(-3.740)\end{array}$ & $\begin{array}{l}-0.260 \\
(-3.670)\end{array}$ & $\begin{array}{c}-0.279 \\
(-3.350)\end{array}$ \\
\hline _RSQUARE & 0.146 & 0.199 & 0.716 & 0.676 \\
\hline
\end{tabular}

T-statistics in parentheses. All regressions include state dummies. Models include all control variable from Table 3.

Regulatory activity models (INSP and ENF) use Negative Binomial model. Pollution quantity models use Log(pollution) in OLS model. 


\section{TABLE 6}

RESIDUAL CORRELATIONS

$\begin{array}{lclllllll} & \text { AIRINSP } & \text { AIRENF } & \text { WATINSP } & \text { WATENF } & \text { PM10 } & \text { SO2 } & \text { TSS } & \text { BOD } \\ \text { AIR INSP } & 1.0000 & & & & & & & \\ \text { AIR ENF } & 0.0962 & 1.0000 & & & & & & \\ \text { WATER INSP } & 0.0088 & 0.0213 & 1.0000 & & & & & \\ \text { WATER ENF } & 0.0012 & 0.0442 & 0.0602 & 1.0000 & & & \\ \text { PM10 } & 0.1268 & 0.0620 & 0.0159 & 0.0133 & 1.0000 & & \\ \text { SO2 } & 0.0984 & 0.0448 & 0.0082 & 0.0261 & 0.5528 & 1.0000 & \\ \text { TSS } & 0.0700 & 0.0777 & 0.1125 & 0.0145 & 0.2226 & 0.1648 & 1.0000 & \\ \text { BOD } & 0.0434 & 0.0628 & 0.0586 & 0.0010 & 0.1935 & 0.0853 & 0.8020 & 1.0000\end{array}$

Residuals are taken from models in Tables 4 and 5 .

Sample sizes differ, based on plants with both variables present. 
TABLE 7

EXTENDED AIR BENEFITS MODEL WITH SORTING

\begin{tabular}{|c|c|c|c|c|}
\hline DEPVAR & AIR INSP & AIR ENF & PM10 & $\mathrm{SO} 2$ \\
\hline NOBS & 4032 & 4032 & 3107 & 3107 \\
\hline AIRBEN & $\begin{array}{c}0.136 \\
(1.710)\end{array}$ & $\begin{array}{c}-0.370 \\
(-1.440)\end{array}$ & $\begin{array}{c}-0.056 \\
(-0.490)\end{array}$ & $\begin{array}{c}1.036 \\
(5.810)\end{array}$ \\
\hline $\begin{array}{l}\text { AIRBEN* } \\
\text { OUT-STATE }\end{array}$ & $\begin{array}{c}0.016 \\
(0.570)\end{array}$ & $\begin{array}{c}-0.082 \\
(-0.960)\end{array}$ & $\begin{array}{c}0.100 \\
(2.150)\end{array}$ & $\begin{array}{c}0.231 \\
(3.210)\end{array}$ \\
\hline $\begin{array}{l}\text { AIRBEN* } \\
\text { OUT-STATE* } \\
\text { GREEN VOTE }\end{array}$ & $\begin{array}{c}0.000 \\
(0.850)\end{array}$ & $\begin{array}{c}0.003 \\
(1.840)\end{array}$ & $\begin{array}{c}-0.002 \\
(-1.850)\end{array}$ & $\begin{array}{c}-0.002 \\
(-1.920)\end{array}$ \\
\hline $\begin{array}{l}\text { AIRBEN* } \\
\text { POOR }\end{array}$ & $\begin{array}{c}-0.505 \\
(-1.070)\end{array}$ & $\begin{array}{c}-2.654 \\
(-1.680)\end{array}$ & $\begin{array}{c}-3.183 \\
(-4.390)\end{array}$ & $\begin{array}{c}1.157 \\
(1.090)\end{array}$ \\
\hline $\begin{array}{l}\text { AIRBEN* } \\
\text { POOR* } \\
\text { SORTING }\end{array}$ & $\begin{array}{c}0.014 \\
(1.280)\end{array}$ & $\begin{array}{c}0.028 \\
(0.810)\end{array}$ & $\begin{array}{c}0.089 \\
(5.310)\end{array}$ & $\begin{array}{l}-0.019 \\
(-0.760)\end{array}$ \\
\hline SORTING & $\begin{array}{c}0.002 \\
(0.120)\end{array}$ & $\begin{array}{l}-0.015 \\
(-0.350)\end{array}$ & $\begin{array}{c}-0.072 \\
(-3.190)\end{array}$ & $\begin{array}{l}-0.040 \\
(-1.470)\end{array}$ \\
\hline $\begin{array}{l}\text { AIRBEN* } \\
\text { ELDERS }\end{array}$ & $\begin{array}{c}-0.555 \\
(-1.990)\end{array}$ & $\begin{array}{c}1.571 \\
(1.900)\end{array}$ & $\begin{array}{c}-0.452 \\
(-1.140)\end{array}$ & $\begin{array}{l}-3.873 \\
(-6.360)\end{array}$ \\
\hline $\begin{array}{l}\text { AIRBEN* } \\
\text { KIDS }\end{array}$ & $\begin{array}{c}-2.093 \\
(-2.920)\end{array}$ & $\begin{array}{c}-0.218 \\
(-0.100)\end{array}$ & $\begin{array}{c}-0.902 \\
(-0.900)\end{array}$ & $\begin{array}{c}-7.880 \\
(-4.930)\end{array}$ \\
\hline $\begin{array}{l}\text { AIRBEN* } \\
\text { NONWHITE }\end{array}$ & $\begin{array}{c}0.087 \\
(2.030)\end{array}$ & $\begin{array}{c}0.383 \\
(3.190)\end{array}$ & $\begin{array}{c}-0.155 \\
(-2.760)\end{array}$ & $\begin{array}{c}-0.482 \\
(-5.270)\end{array}$ \\
\hline $\begin{array}{l}\text { CANAD IAN } \\
\text { BORDER }\end{array}$ & $\begin{array}{c}0.005 \\
(0.070)\end{array}$ & $\begin{array}{c}0.589 \\
(3.370)\end{array}$ & $\begin{array}{c}0.152 \\
(1.440)\end{array}$ & $\begin{array}{l}-0.622 \\
(-4.750)\end{array}$ \\
\hline TURNOUT & $\begin{array}{c}0.537 \\
(1.300)\end{array}$ & $\begin{array}{c}-0.978 \\
(-0.870)\end{array}$ & $\begin{array}{c}0.297 \\
(0.470)\end{array}$ & $\begin{array}{c}1.900 \\
(2.290)\end{array}$ \\
\hline $\begin{array}{l}\text { TURNOUT * } \\
\text { CONVMEMB }\end{array}$ & $\begin{array}{c}-0.061 \\
(-1.830)\end{array}$ & $\begin{array}{c}0.172 \\
(2.170)\end{array}$ & $\begin{array}{l}-0.129 \\
(-3.240)\end{array}$ & $\begin{array}{c}-0.189 \\
(-3.540)\end{array}$ \\
\hline _RSQUARE & 0.197 & 0.131 & 0.654 & 0.489 \\
\hline
\end{tabular}

T-statistics in parentheses. All regressions include state dummies. Models include all control variable from Table 2.

AIRBEN row is PMBEN and SO2BEN for PM10 and SO2 models.

Regulatory activity models (INSP and ENF) use Negative Binomial model. Pollution quantity models use Log(pollution) in OLS model. 
TABLE 8

EXTENDED WATER BENEFITS MODEL WITH SORTING

\begin{tabular}{|c|c|c|c|c|}
\hline _DEPVAR & WATER INSP & WATER ENF & TSS & BOD \\
\hline _NOBS & 2134 & 2134 & 1362 & 1362 \\
\hline WATER BEN & $\begin{array}{l}-0.005 \\
(-0.230)\end{array}$ & $\begin{array}{c}0.117 \\
(1.340)\end{array}$ & $\begin{array}{c}-0.207 \\
(-4.670)\end{array}$ & $\begin{array}{l}-0.331 \\
(-7.720)\end{array}$ \\
\hline $\begin{array}{l}\text { WATER BEN* } \\
\text { OUT-STATE }\end{array}$ & $\begin{array}{l}-0.084 \\
(-2.810)\end{array}$ & $\begin{array}{c}0.007 \\
(0.070)\end{array}$ & $\begin{array}{c}0.062 \\
(1.100)\end{array}$ & $\begin{array}{l}0.213 \\
(3.650)\end{array}$ \\
\hline $\begin{array}{l}\text { WATER BEN* } \\
\text { OUT-STATE } \\
\text { GREEN VOTE }\end{array}$ & $\begin{array}{c}0.001 \\
(2.290)\end{array}$ & $\begin{array}{c}-0.003 \\
(-1.160)\end{array}$ & $\begin{array}{c}-0.002 \\
(-1.840)\end{array}$ & $\begin{array}{l}-0.003 \\
(-3.190)\end{array}$ \\
\hline $\begin{array}{l}\text { WATER BEN* } \\
\text { POOR }\end{array}$ & $\begin{array}{c}0.126 \\
(0.360)\end{array}$ & $\begin{array}{l}7.029 \\
(2.960)\end{array}$ & $\begin{array}{c}6.061 \\
(7.880)\end{array}$ & $\begin{array}{l}3.836 \\
(5.470)\end{array}$ \\
\hline $\begin{array}{l}\text { WATER BEN* } \\
\text { POOR* } \\
\text { SORTING }\end{array}$ & $\begin{array}{l}-0.003 \\
(-0.330)\end{array}$ & $\begin{array}{c}-0.183 \\
(-3.570)\end{array}$ & $\begin{array}{l}-0.120 \\
(-7.450)\end{array}$ & $\begin{array}{l}-0.054 \\
(-3.550)\end{array}$ \\
\hline SORTING & $\begin{array}{c}0.003 \\
(0.490)\end{array}$ & $\begin{array}{c}0.095 \\
(2.420)\end{array}$ & $\begin{array}{c}0.063 \\
(4.440)\end{array}$ & $\begin{array}{c}0.035 \\
(2.830)\end{array}$ \\
\hline $\begin{array}{l}\text { WATER BEN* } \\
\text { NONWHITE }\end{array}$ & $\begin{array}{c}-0.071 \\
(-1.210)\end{array}$ & $\begin{array}{l}0.256 \\
(0.900)\end{array}$ & $\begin{array}{l}-0.158 \\
(-1.280)\end{array}$ & $\begin{array}{l}-0.359 \\
(-2.630)\end{array}$ \\
\hline $\begin{array}{l}\text { CANADIAN } \\
\text { BORDER }\end{array}$ & $\begin{array}{l}-0.021 \\
(-0.370)\end{array}$ & $\begin{array}{l}-0.435 \\
(-1.740)\end{array}$ & $\begin{array}{c}0.032 \\
(0.300)\end{array}$ & $\begin{array}{c}0.446 \\
(4.830)\end{array}$ \\
\hline TURNOUT & $\begin{array}{l}1.434 \\
(3.590)\end{array}$ & $\begin{array}{l}2.638 \\
(1.250)\end{array}$ & $\begin{array}{l}3.921 \\
(5.050)\end{array}$ & $\begin{array}{c}6.155 \\
(6.920)\end{array}$ \\
\hline $\begin{array}{l}\text { TURNOUT * } \\
\text { CONVMEMB }\end{array}$ & $\begin{array}{l}-0.065 \\
(-2.420)\end{array}$ & $\begin{array}{c}-0.654 \\
(-3.140)\end{array}$ & $\begin{array}{c}-0.174 \\
(-2.500)\end{array}$ & $\begin{array}{l}-0.258 \\
(-2.810)\end{array}$ \\
\hline _RSQUARE & 0.146 & 0.206 & 0.727 & 0.679 \\
\hline
\end{tabular}

T-statistics in parentheses. All regressions include state dummies. Models include all control variable from Table 3.

Regulatory activity models (INSP and ENF) use Negative Binomial model. Pollution quantity models use Log(pollution) in OLS model. 